\title{
Effect of Various Precursors on ZnO Thin Films by USP Technique
}

\author{
Hilal Kübra SAĞLAM ${ }^{1 *}$ (D) Sevda SARITAŞ ${ }^{2}$ (D) Mehmet ERTUĞRUL $^{3}$ \\ ${ }^{1}$ Department of Electricity and Energy, Vocational College of Technical Sciences, Ataturk University, \\ 25240 Erzurum, Turkey \\ 2 Department of Electricity and Energy, Vocational College of İspir Hamza Polat, Ataturk University, \\ 25240 Erzurum, Turkey \\ ${ }^{3}$ Department of Electrical and Electronic Engineering, Faculty of Engineering, Ataturk University, 25240 \\ Erzurum, Turkey
}

Geliş / Received: 13/10/2021, Kabul / Accepted: 09/12/2021

\begin{abstract}
$\mathrm{ZnO}$ is one of the main materials used in thin film coating due to its low cost and advantageous properties. The aim of this study is to examine the optical, morphological and structural properties of zinc oxide thin films coated with ultrasonic spray pyrolysis(USP) technique. $\mathrm{ZnO}$ thin films were grown at $450^{\circ} \mathrm{C}$ using different precursor solutions such as zinc acetate and zinc nitrate. Glass substrate was used in these processes. $0.1 \mathrm{M}$ and $100 \mathrm{~mL}$ solutions were prepared. Growth orientations according to XRD patterns are (002). Bandgap values for zinc acetate and zinc nitrate were measured as $3.25 \mathrm{eV}$ and $3.13 \mathrm{eV}$, respectively. In addition, as can be seen from the Debye-Scherrer calculations, the $\mathrm{ZnO}$ grain size of the films obtained with zinc acetate, which was chosen as the precursor salt, is almost the same as the film obtained with zinc nitrate, which was chosen as the precursor salt. Finally, the amount of oxygen in $\mathrm{ZnO}$ films varies depending on different solutions and zinc salts.
\end{abstract}

Keywords: Gas Sensor, Thin Film, ZnO Thin Film, Ultrasonic Spray Pyrolysis(USP).

\section{USP Tekniği ile Çeşitli Öncülerin ZnO İnce Filmler Üzerindeki Etkisi}

\section{$\ddot{O} z$}

$\mathrm{ZnO}$ düşük maliyetinden ve sahip olduğu avantajlı özelliklerinden dolayı ince film kaplamada kullanılan başlıca malzemelerdendir. Bu çalışmanın amacı, ultrasonik sprey piroliz (USP) tekniği ile kaplanmış çinko oksit ince filmlerin optik, morfolojik ve yapısal özelliklerini incelemektir. ZnO ince filmler, çinko asetat ve çinko nitrat gibi farklı öncü çözeltiler kullanılarak $450^{\circ} \mathrm{C}^{\prime} \mathrm{de}$ büyütülmüştür. Bu işlemlerde cam altlık kullanılmıştır. 0.1M ve $100 \mathrm{~mL}$ çözeltiler hazırlanmıştır. XRD desenlerine göre büyüme yönelimleri (002) şeklindedir. Çinko asetat ve çinko nitrat için bandgap değerleri sırasıyla, $3.25 \mathrm{eV}$ ve $3.13 \mathrm{eV}$ olarak ölçülmüştür. Ayrıca Debye-Scherrer hesaplamalarından anlaşıldığı üzere öncü tuz olarak seçilen çinko asetat ile elde edilen filmlerin $\mathrm{ZnO}$ tane boyutu öncü tuz olarak seçilen çinko nitrat ile elde edilen filmle hemen hemen aynıdır. Son olarak $\mathrm{ZnO}$ filmlerdeki oksijen miktarı farklı çözeltilere ve çinko tuzlarına bağlı olarak farklılık gösterir.

Anahtar Kelimeler: Gaz Sensörü, İnce Film, ZnO İnce Film, Ultrasonik Sprey Piroliz(USP).

\section{Introduction}

Today, the increasing need for semiconductors has triggered the growth of the semiconductor industry. The rapid growth of this industry; has led to the development of compact devices 
with high performance, flexibility and low cost. Products in nanotechnology contain very small particles and also show some advantageous properties. Therefore, it is one of the new and active areas in thin film technology. Because this technology allows the deposition of very thin layers of semiconductor material. Produced materials; exhibits new properties that will benefit electrical, chemical, mechanical and optical aspects. Thin film can be defined as a very thin layer of material deposited on a substrate. This very thin layer of material usually has a thickness ranging from $10 \mathrm{~nm}$ to $1-2 \mu \mathrm{m}$. Although the deposition process can be physical or chemical, it occurs by the regular condensation of ions, molecules or vapors. Thin films are deposited on a wide variety of substrates. The substrates can be in amorphous, monocrystalline or polycrystalline forms. Thin films and bulk materials have different properties. While a bulk material is stable, the properties of a thin film may vary depending on the quality of the surface. These features can be improved with some modifications. For example, the quality can be increased by doping change, thickness change or various surface treatments. However, multilayer thin films may exhibit unknown properties. With thin film technology, raw materials can be used more efficiently. Thin films deposited using nanotechnology have been used in sensors, photovoltaic devices, batteries, and information storage devices in recent years(Özgür et al., 2005; Nalwa, 2001; Sheu et al., 2008; Hosono, 2007; Patil et al., 2011; Bari et al., 2013; Lin and Wu, 2010; Zhou et al., 2007; Walsh et al., 2008). In particular, oxide-based semiconductors such as $\mathrm{ZnO}$, silicon, GaN, gallium arsenide and others remain popular(Vyas, 2020). In addition, $\mathrm{ZnO}$ is the priority material for nanoelectronic devices due to some of its properties. Some of these features are: optical, electrical, magnetic and most importantly gas detection(Wasa et al., 2004). The different nanostructures of $\mathrm{ZnO}$ include nanorods, nanowires, nanotubes and nanostrips. Single-crystal $\mathrm{ZnO}$ can be used to manufacture high-performance electronic and optoelectronic devices. Because in this way, low-defect epitaxial films are obtained. It can be deposited on a variety of substrates using conventional thin-film deposition methods such as sputtering, thermal evaporation, and sol-gel(Özgür et al., 2005). Since the processing temperature of $\mathrm{ZnO}$ nanostructures is low, inexpensive substrates such as glass and plastic may also be preferred. In addition, the optical and electrical properties of $\mathrm{ZnO}$ allow for post-deposition treatments such as doping, surface treatments, and annealing. It can be selected as a transparent conductor for near-UV emission and detection. Because it is an n-type transparent material with high electrical conductivity and a direct band gap(Vyas et al., 2020). ZnO has a wide band gap of $3.3 \mathrm{eV}$ and a low resistivity of $5 \times 10^{-4} \Omega \cdot \mathrm{cm}$ (Agrawal et al., 2013). Transparent Conductive Oxides (TCOs) are often doped metal oxide layers used in optical surfaces such as photovoltaic panels, architectural and transmission glass, and interactive devices such as touch panels. Chemical inertness and high transparency are the main factors contributing to the TCO selection(Engle, 2021). Transparent conductive oxide (TCO) films are used in many optoelectronic devices. Each parameter involved in the process affects various material properties such as crystal quality(Arnou et al., 2014). TCO thin films have been crucial in the design of existing devices in sensors, photovoltaics, microelectronics, and optoelectronics(Benzarouk et al., 2019). Currently, the most widely used TCO is indium-doped indium oxide (ITO). This is because this type of material offers a great combination of high transparency and high electrical conductivity. Unfortunately, because indium is a rare element, an alternative TCO material was needed. In this context, zinc oxide ( $\mathrm{ZnO})$ has 
become an alternative metal oxide(Arnou et al., 2014). Because $\mathrm{ZnO}$ thin films are abundant in nature. They are also non-toxic. The reasons why it is often preferred among other TCO materials is that it has many advantages. These advantages can be listed as follows: High optical transmittance in the visible region, high chemical stability, high thermal stability(Arnou et al., 2014; Benzarouk et al., 2019). The USP technique is simple, cheap and suitable for pure production. For this reason, the process of preparing $\mathrm{ZnO}$ films by spraying an aqueous solution has been popular in recent years. Many studies have focused on the effect of different precursor solutions on some properties of $\mathrm{ZnO}$ thin films(Benzarouk et al., 2019). Also although months have passed, doped $\mathrm{ZnO}$ nanoroads seem to have higher sensitivity and stability than pure $\mathrm{ZnO}$ nanoroads(Kasapoğlu et al., 2021). As we mentioned before, $\mathrm{ZnO}$ has attracted attention among many metal oxide materials. In addition to other advantages, it has physical properties such as good piezoelectric behavior and high electron mobility. Undoped and doped n-type $\mathrm{ZnO}$ are used in TCO application areas. Apart from simple and multifunctional chemical deposition methods, magnetron sputtering, pulsed laser, and plasmaassisted molecular beam epitaxy are known vacuum-based deposition techniques for producing $\mathrm{ZnO}$ thin films. Silar, spray pyrolysis, chemical bath deposition and sol-gel methods are the most prominent among the non-vacuum process thin film deposition techniques(Tumbul, 2019). Vacuum deposition systems require high installation costs. So avoiding these techniques can reduce production costs. Ultrasonic spray pyrolysis (USP) is a low-cost, simple atmospheric deposition technique and can be applied to vacuum-based systems(Arnou et al., 2014; Ynineb et al., 2013). Among the many deposition techniques mentioned, USP is the most suitable even for the preparation of doped oxide thin films. Because in addition to being simple and inexpensive, it can be easily adapted to large area accumulation(Supriyono et al., 2015). TCO conventional materials such as $\mathrm{In} 2 \mathrm{O} 3, \mathrm{SnO} 2$, $\mathrm{ZnO}$ and $\mathrm{CdO}$ have been extensively studied. These properties have created an opportunity to be used as a transparent front contact material in solar cells and for $\mathrm{ZnO}$ films to be a potential candidate for photosensors, gas sensors, optoelectronic and photocatalytic applications(Atay et al., 2019). Being preferred in light emitting diodes (LEDs), laser diodes, solar cell, photodetectors, electronic devices, optoelectronic and photocatalytic applications, it offers a wide range of uses considering both energy platforms and environmental factors. Especially when it comes to sensor applications, it is necessary to increase the sensitivity of $\mathrm{ZnO}$, and for this reason, many studies have been done. Research has shown that increasing the surface area of the material by itself can be a solution. That is, making a larger surface allows to obtain an advantageous $\mathrm{ZnO}$ nanostructure. For this, it is necessary to manipulate the structure itself in a certain way(Ramadhani et al., 2014). In general, the physical properties of $\mathrm{ZnO}$ are related to its microstructure. Depending on the precursor materials chosen, the morphology of $\mathrm{ZnO}$ can be controlled. One of the advantages of the pyrolytic decomposition of its precursors in this context is that crystallographic orientations can be taken over by the resulting $\mathrm{ZnO}$. Hence, the microstructure of $\mathrm{ZnO}$ can be divided into hexagonal plates or prisms (Figure 1)(Yuki et al., 2015). 


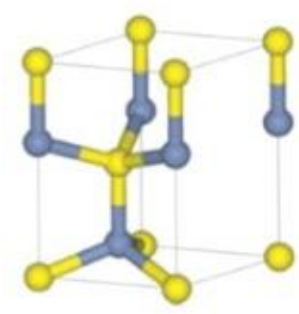

(a)

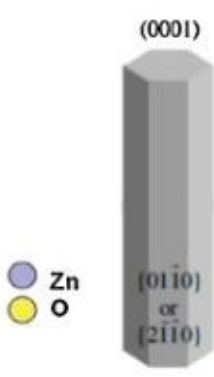

(b)

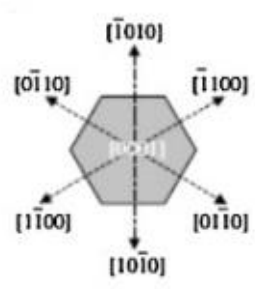

(c)

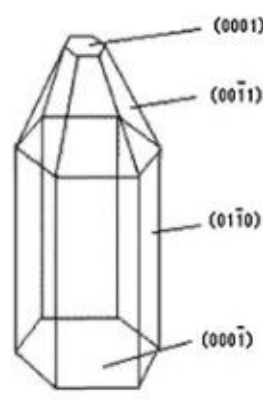

(d)

Figure 1. Unit cell of $\mathrm{ZnO}$ crystal structure(Skompska and Zarebska, 2014)

The character of the selected doping element varies according to certain conditions. These conditions are: the adsorption of oxygen during the deposition process, the film deposition temperature and the post deposition annealing atmosphere. Therefore, the opto-electrical properties of $\mathrm{ZnO}$ depend on the conditions both during and after deposition(Agrawal et al., 2013). USP; The simplicity of the experimental setup, the ability to add the material at desired rates, and the ability to produce homogeneous, cheap and easy in large areas(Malik et al., 2015; Bilgin et al., 2010; Lalasari et al., 2018; Kaleli et al., 2019). As a USP solution-based inexpensive method, it offers the possibility to easily adjust the deposition parameters depending on the desired material properties. In addition, the USP is both material-efficient and can be manufactured in a wide range(Arnou et al., 2014). $\mathrm{ZnO}$ nanoparticles can be obtained even at the lowest reaction temperature. Thanks to effective sintering, $\mathrm{ZnO}$ porous particles formed by the aggregation of $\mathrm{ZnO}$ nanoparticles were prepared at higher temperatures. The results showed that the properties of $\mathrm{ZnO}$ particles can be controlled by changing the reaction temperature in the ultrasonic spray pyrolysis method(Ebin et al., 2012).

In this paper, by using different precursors the structural, morphological and optical properties of zinc oxide thin films were investigated. At low temperatures, other atoms can form instead of oxygen. $450{ }^{\circ} \mathrm{C}$ degrees was preferred to obtain the oxide film.

\section{Material and Methods}

Ultrasonic spray pyrolysis technique is preferred because it is more economical than other techniques, it is suitable for intervention in the production process, there is no need for a vacuum environment for thin film production. It allows the coating of large surfaces and the production process can be followed step by step.

Three steps are followed to apply this method, which is a thin film production technique:

- Cleaning Step

- Solution Preparation with deionized water

- Thin Film Production by USP method 
Glasses washed with soapy water are then exposed to ethanol and propyl alcohol solutions. Afterwards, the drying process is carried out.

\subsection{Precursor Zinc Nitrate}

In this process, 0.1 Molar and $100 \mathrm{~mL}$ solution was prepared using $2.972 \mathrm{~g}$ of zinc nitrate with a molecular weight of $297.2 \mathrm{~g}$ to be grown at $450^{\circ} \mathrm{C}$ for an hour on glass substrate using the spray pyrolysis. $\left(0.01 \mathrm{~mol} \mathrm{Zn}\left(\mathrm{NO}_{3}\right)_{2} \cdot 6 \mathrm{H}_{2} \mathrm{O}: 2.972 \mathrm{~g}\right)$

\subsection{Precursor Zinc Acetate}

In this process, 0.1 Molar and $100 \mathrm{~mL}$ of solution were prepared using $2.1949 \mathrm{~g}$ of zinc acetate with a molecular weight of $219.49 \mathrm{~g}$ to be grown at $450{ }^{\circ} \mathrm{C}$ for an hour on glass substrate using the spray pyrolysis. $\left(0.01 \mathrm{~mol} \mathrm{Zn}\left(\mathrm{CH}_{3} \mathrm{COO}\right)_{2} \cdot 2 \mathrm{H}_{2} \mathrm{O}: 2.1949 \mathrm{~g}\right)$

Spray nozzle with nozzle frequency $100 \mathrm{kHz}$ was placed at a 45 degree angle of $30 \mathrm{~cm}$ from the table. $100 \mathrm{~mL}$ of solution was sprayed for 1 hour, the flow rate was 0.028 milliliters/second.

\section{Experimental Results}

X-ray diffraction (XRD), absorption and scanning electron microscopy (SEM) were used to examine the crystal structure and surface morphology analysis of the films, respectively.

\subsection{Crystal Structure}

$\mathrm{XRD}$ results showed that thin $\mathrm{ZnO}$ films were produced by ultrasonic sputtering technique. The main peaks of $\mathrm{ZnO}$ are visibled.

a)

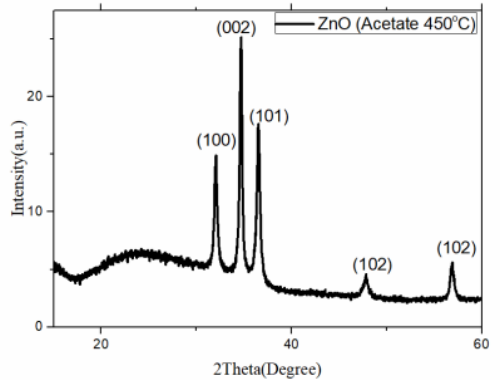

b)

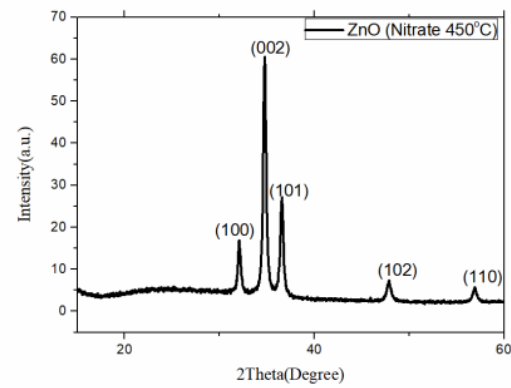

Figure 2. XRD graphs of $\mathrm{ZnO}$ a) Zinc Acetate b) Zinc Nitrate (Reference Code: 01-0790205)

In Figure 2, different salt forms of zinc are used at constant temperature. Figure 3 shows the shift caused by these changed parameters. Both $\mathrm{ZnO}$ structures are in hexagonal structure and it is seen that they are oriented along the c axis (002) direction. In addition, as seen in Figure 3, the XRD peak intensities of the films obtained from nitrate salt solution are higher than acetate salt. 


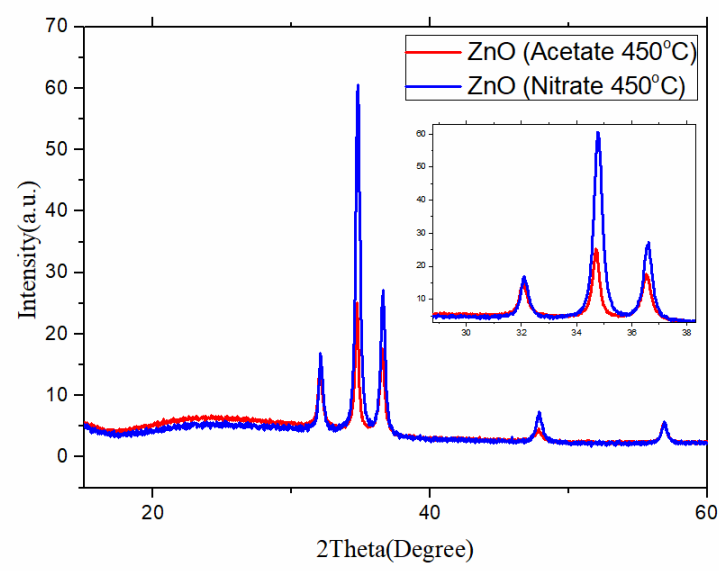

Figure 3. XRD graphs of Zinc Acetate and Zinc Nitrate at $450^{\circ} \mathrm{C}$

Debye-Scherrer formula,

$$
\mathrm{D}=0,94 * \lambda / \beta \cos \theta
$$

where $\lambda$ is the wavelength $(\lambda=1.5405 \AA), \beta$ is the full width at half maximum (FWHM) of the considerate peak and $\theta$ is the corresponding Bragg's angle. As seen in Table 1, the grain size values of the samples grown from different precursors according to the Debye-Scherrer method calculated in Equation 1 are approximately the same. However, with a slight difference, grain size of zinc acetate is larger than the grain size of zinc nitrate according to the average grain size values. Average of grain sizes for zinc nitrate and zinc acetate are $19,72 \mathrm{~nm}$ and $19,88 \mathrm{~nm}$, respectively.

Table 1. Crystal size of thin films

\begin{tabular}{|c|c|c|c|c|}
\hline & \multicolumn{2}{|c|}{ Zinc Nitrate } & \multicolumn{2}{c|}{ Zinc Acetate } \\
\hline $2 \theta$ & $\beta$ & $\mathrm{D}(\mathrm{nm})$ & $\beta$ & $\mathrm{D}(\mathrm{nm})$ \\
\hline 32,10 & 0,36 & 22,4 & 0,37 & 22,3 \\
\hline 34,75 & 0,38 & 21,6 & 0,31 & 26,1 \\
\hline 35,59 & 0,40 & 20,8 & 0,44 & 18,6 \\
\hline 47,88 & 0,54 & 16,1 & 0,67 & 12,8 \\
\hline 56,93 & 0,51 & 17,7 & 0,46 & 19,6 \\
\hline
\end{tabular}



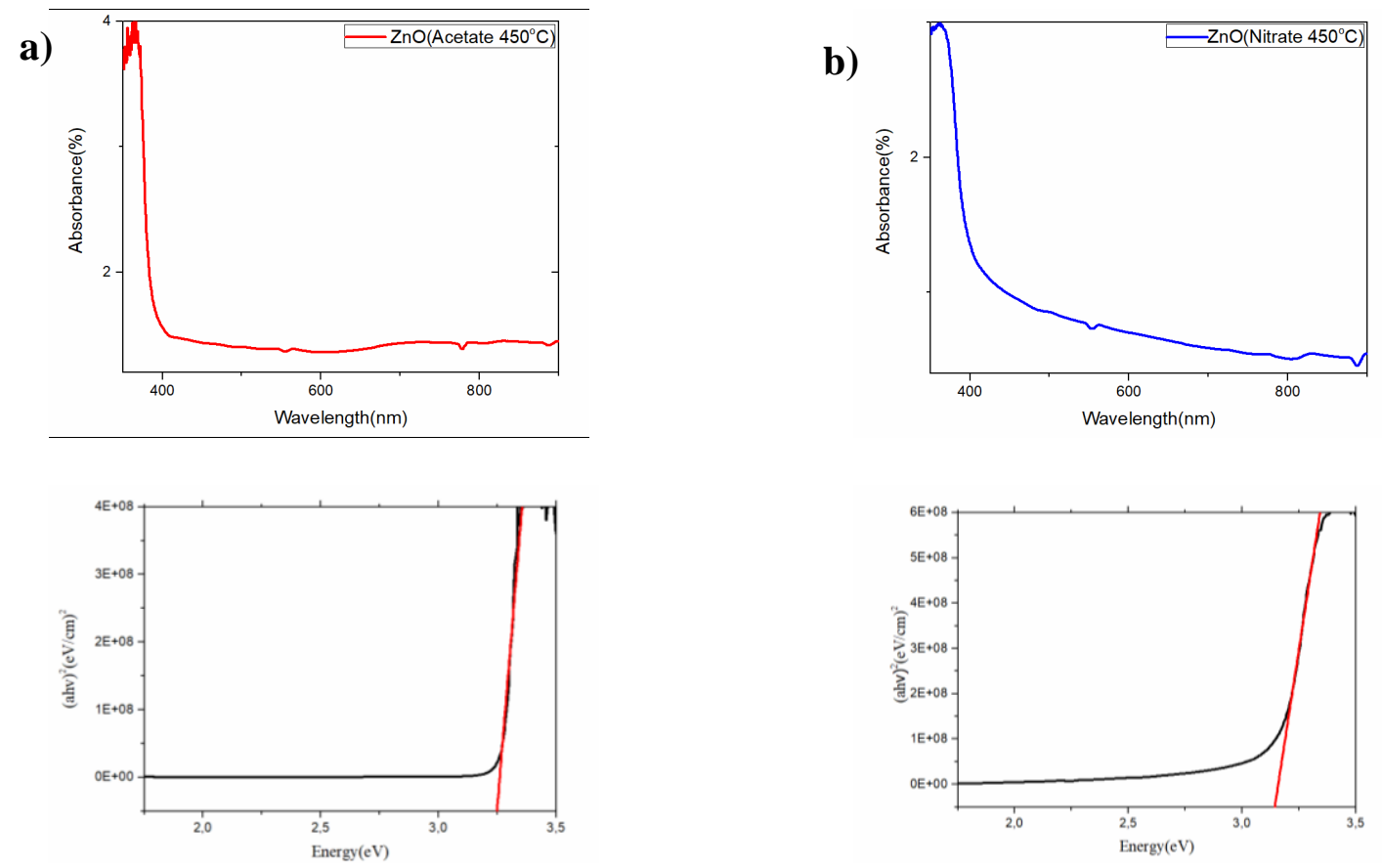

Figure 4. Absorption measurements, bandgap plots of $\mathrm{ZnO}$ films at $450^{\circ} \mathrm{C}$

a) Zinc Acetate b)Zinc Nitrate

As seen in Figure 4, the absorption graphs differ according to the salt component used in the solution, and there is a remarkable change in the size of the band gap.

The optical band gap $\left(E_{g}\right)$ values were determined from the commonly known equation (for $\mathrm{n}=0.5)$ :

$$
\mathrm{ah} v=\mathrm{A}\left(\mathrm{h} v-\mathrm{E}_{\mathrm{g}}\right){ }^{(1 / \mathrm{n})}
$$

The band gap of the thin film obtained with salt containing acetate is around $3.25 \mathrm{eV}$, while the band gap gap of the films obtained with salt containing nitrate is around $3.13 \mathrm{eV}$. The band gap values above were calculated according to Equation 2.

\subsection{Surface Morphology}

As can be seen from the SEM image (Fig. 5), it is seen that the grain size of the $\mathrm{ZnO}$ structure obtained with zinc nitrate salt is similarly the structure made with zinc acetate salt, and the difference in XRD peak intensity supports this situation.
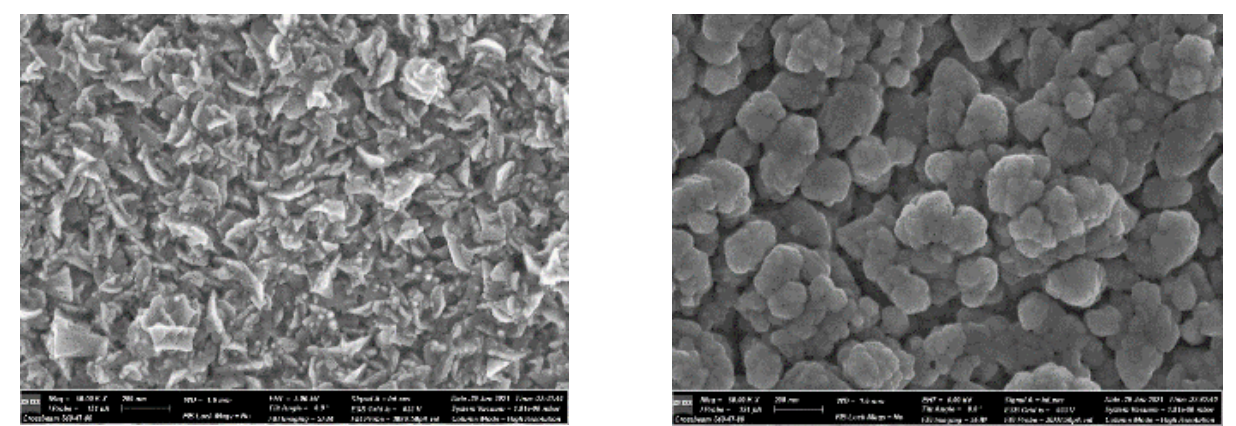

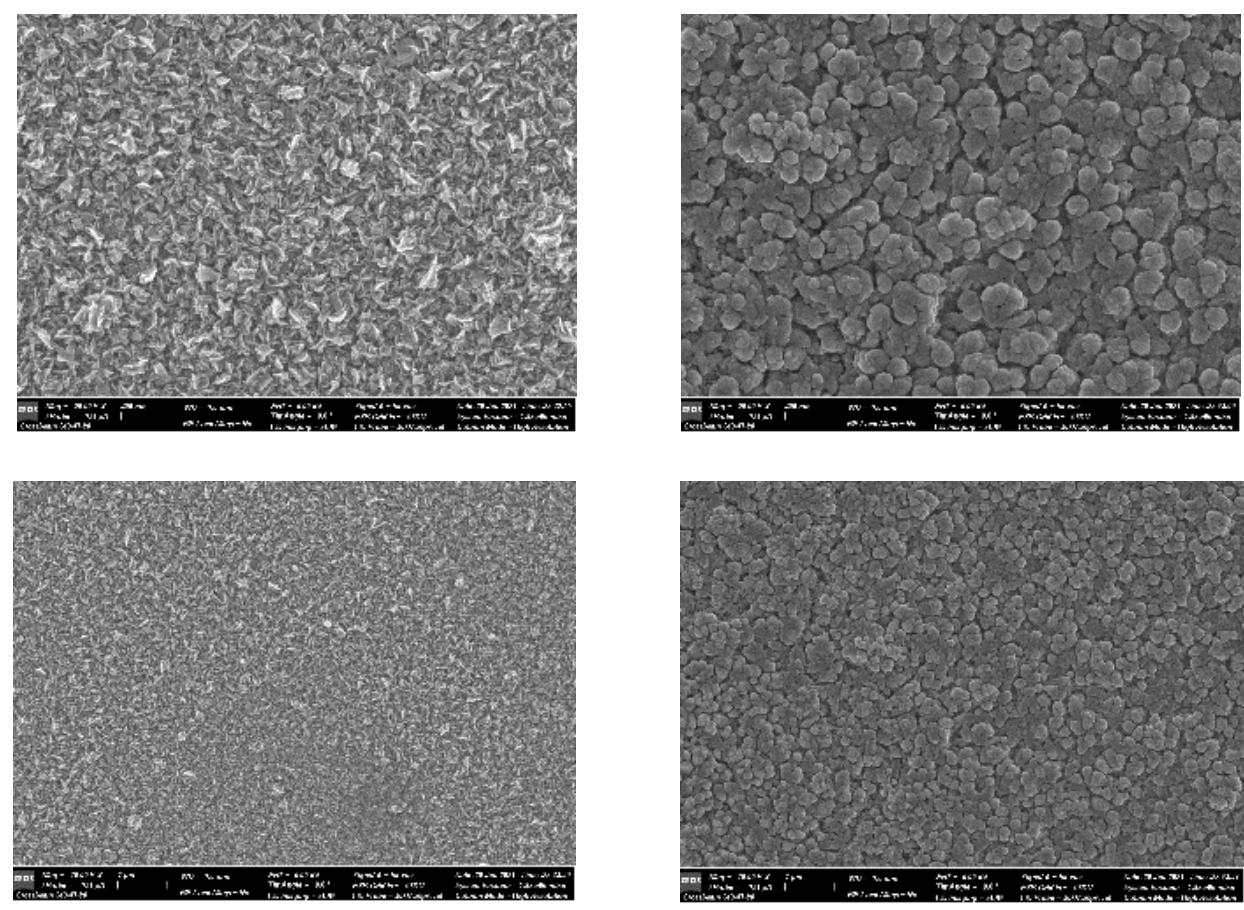

Figure 5. SEM micrographs of $\mathrm{ZnO}$ films (200nm-400nm-1 $\mu \mathrm{m})$ a)Zinc Acetate b) Zinc Nitrate

\section{Conclusion}

Thin $\mathrm{ZnO}$ films can be produced by ultrasonic spray coating. It is possible to produce gas sensors on transparent surfaces without losing their transparency. However, transparencyperformance optimization should be made between sensor performance and film thickness. Performance-transparency optimization should be made especially in order to produce gas sensors without losing transparency. In our study, it has been observed that thin $\mathrm{ZnO}$ films can be produced by ultrasonic spray coating. $\mathrm{ZnO}$ thin films were produced at $450^{\circ} \mathrm{C}$ for two hours using the spray pyrolysis technique. Deposits were made on glass substrates.

Film prepared with zinc acetate solution has higher transmittance compared to films prepared with other zinc precursors. The calculated band gap of the $\mathrm{ZnO}$ films obtained using different precursor salts is lower than the band gap of the bulk $\mathrm{ZnO}$ crystal. It has also been observed that it is strongly affected by stress(Lehraki et al., 2020).

The precursor zinc acetate and precursor zinc nitrate used in these processes are $0.1 \mathrm{M}$ and 100 $\mathrm{mL}$. The morphological features of the prepared films were analyzed. The bandgap values of the films obtained from zinc acetate and zinc nitrate precursor solutions were $3.25 \mathrm{eV}$ and $3.13 \mathrm{eV}$, respectively. In addition, differences in crystal shapes were observed when the precursor solutions were changed. In the USP technique, both the cost is low and the parameters can be changed easily. The crystal size and surface morphology of the structures obtained by ultrasonic spray pyrolysis are promising for the preparation of a sensitive gas sensor. 


\section{References}

Agrawal, S., Rane, R., Mukherjee, S. 2013. "ZnO Thin Film Deposition for TCO Application in Solar Cell”, Hindawi Publishing Corporation Conference Papers in Energy Volume 2013, Article ID 718692, 7 pages.

Arnou, P., Bowers, J.W., Walls, J.M. 2014. "Aluminium-Doped Zinc Oxide Deposited by Ultrasonic Spray Pyrolysis for Thin Film Solar Cell Applications", IEEE 40th Photovoltaic Specialist Conference (PVSC).

Atay, F., Akyuz, I., Durmaz, D., Köse, S.. 2019. "Characterization of ZnO-SnO2 Oxide Systems Produced by Ultrasonic Spray Pyrolysis", Solar Energy, Volume 193, Pages 666675.

Bari, R.H., Patil, P.P., Patil, S.B., Bari, A.R. 2013. "Detection of H2S gas at lower operating temperature using sprayed nanostructured $\mathrm{In}_{2} \mathrm{O}_{3}$ thin films", Bull. Mater. Sci., 36, (6), 967.

Benzarouk, H., Mekhnache, M., Drici, A., Amara, A. 2019. "Effect of The Precursor Solution on The Structural Morphological and Optical Properties of Zno Thin Films Deposited by Spray Pyrolysis Technique for Solar Cell Application", International Journal Of Scientific Research \& Engineering Technology (IJSET), Vol 10 pp 45-49.

Bilgin V., Akyuz I., Ketenci E., Kose S., Atay F. 2010. "Electrical, Structural and Surface Properties of Fluorine Doped Tin Oxide Films", Applied Surface Science, vol. 256, no. 22, pp. 6586-6591.

Ebin, B., Arıg, E., Özkal, B., Gürmen, S. 2012. "Production and characterization of ZnO nanoparticles and porous particles by ultrasonic spray pyrolysis using a zinc nitrate precursor”, International Journal of Minerals Metallurgy and Materials 19(7):651.

Engle, R.W. 2012. "Advantages of TCO via Ultrasonic Spray Under Atmospheric Conditions", 16th International Coating Science and Technology Symposium(ISCST), Atlanta, GA, USA.

Hosono, H. 2007. "Recent progress in transparent oxide semiconductors: Materials and device application", Thin Solid Films, 515, (15), 6000.

Kaleli, M., Aldemir, D.A., Bayram, A.B., Yavru, C.A. 2019. “Ultrasonik Sprey Pirolizile Üretilen Flor Katkılı Kalay Oksit İnce Filmlerin Yapısal, Morfolojik, Optiksel ve Elektriksel Analizleri”, Düzce Üniversitesi Bilim ve Teknoloji Dergisi, 7 2107-2115.

Kasapoğlu, A.E., Habashyani, S., Baltakesmez, A., İskenderoğlu, D., Gür, E. 2021. "The Effect of The Change in The Amount of Sb Doping in $\mathrm{ZnO}$ Nanorods For Hydrogen Gas Sensors", International Journal of Hydrogen Energy, Volume 46, Issue 41, Pages 2171521725.

Lalasari, L.H., Arini, T., Andriyah, L., Firdiyono, F., Yuwono, A.H. 2018. "Electrical, Optical and Structural Properties of FTO Thin Films Fabricated by Spray Ultrasonic Nebulizer Technique from SnCl4 Precursor", AIP Conference Proceedings, p. 020001, Proceedings of the International Seminar on Metallurgy and Materials (ISMM2017).

Lehraki, N., Attaf, A., Aida, M.S., Attaf, N., Othmane, M., Bouaichi, F. 2020. "Effect of different Zinc precursors in Structural and Optical properties of $\mathrm{ZnO}$ thin films", Chemical Physics. https://arxiv.org/abs/2003.08487.

Lin, S.S., Wu, D.K. 2010. "The properties of Al-doped TiO2 nanoceramic films deposited by simultaneous rf and dc magnetron sputtering", Ceram. Int., 36, (1), 87. 
Malik, O., De la Hidalga-Wade, F.J., Amador, R.R. 2015. "Fluorine-doped Tin Oxide Films with A High Figure of Merit Fabricated by Spray Pyrolysis", Journal of Materials Research, vol. 30, no. 13, pp. 2040-2045.

Nalwa, H.S. 2001. Silicon-Based Materials and Devices - Vol. 2, Properties and Devices, Academic Press, San Diego, USA.

Özgür, Ü., Alivov, Y.I., Liu, C., Teke, A., Reshchikov, M.A., Doğan, S., Avrutin, V., Cho, S.J., Morkoç, H. 2005. "A comprehensive review of ZnO materials and devices", J. Appl. Phys.98, (4),041301.

Patil, G.E., Kajale, D.D., Chavan, D.N., Pawar, N.K., Ahire, P.T., Shinde, S.D., Gaikwad, V.B., Jain, G.H. 2011. "Synthesis, characterization and gas sensing performance of SnO2 thin films prepared by spray pyrolysis", Bull. Mater. Sci., 34, (1), 1 .

Ramadhani, M.F., Pasaribu, M.A.H., Yuliarto, B., Nugraha. 2014. "Fabrication of ZnO Nanorod Using Spray-Pyrolysis and Chemical Bath Deposition Method", 5th Nanoscience and Nanotechnology Symposium (NNS2013) AIP Conf. Proc. 1586, 74-77.

Sheu, J., Lee, M., Lu, Y., Shu, K. 2008. “Ga-Doped ZnO Transparent Conductive Oxide Films Applied to GaN-Based Light-Emitting Diodes for Improving Light Extraction Efficiency", IEEE J. Quantum Elect., 44, (12), 1211.

Skompska, M., Zarebska, K. 2014. "Electrodeposition of ZnO Nanorod Arrays on Transparent Conducting Substrates-a Review", Electrochimica Acta, Volume 127, Pages 467488.

Supriyono, Surahman, H., Krisnandi, Y.K., Gunlazuardi. J. 2015. "Preparation and Characterization of Transparent Conductive Sno2-F Thin Film Deposited by Spray Pyrolysis: Relationship Between Loading Level and Some Physical Properties", Procedia Environmental Sciences, $28242-251$.

Tumbul, A. 2019. "Effect of Monoethanolamine Content on the Crystallinity of ZnO Thin Film”, Süleyman Demirel Üniversitesi Fen Edebiyat Fakültesi Fen Dergisi, 14: 155-164.

Vyas, S. 2020. "A Short Review on Properties and Applications of Zinc Oxide Based Thin Films and Devices", Johnson Matthey Technol. Rev., 64, (2), 202-218.

Walsh, A., Da Silva, J.L.F., Wei, S.H., Körber, C., Klein, A., Piper, L.F.J., DeMasi, A., Smith, K.E., Panaccione, G., Torelli, P., Payne, D.J., Bourlange, A., Egdell, R.G. 2008. "Nature of the Band Gap of In2O3 Revealed by First-Principles Calculations and X-Ray Spectroscopy", Phys. Rev. Lett., 2008, 100, (16), 167402.

Wasa, K., Kitabatake, M., Adachi, H. 2004. Thin Film Materials Technology - Sputtering of Compound Materials, William Andrew Inc, Norwich, New York, USA.

Yuki, T., Ueno, S., Hagiwara, M., Fujihara, S. 2015. "Fabrication of Layered Hydroxide Zinc Nitrate Films and Their Conversion to Zno Nanosheet Assemblies for Use in Dye-Sensitized Solar Cells", Journal of Asian Ceramic Societies 3 144-150.

Ynineb, F., Hafdallah, A., Aida, M.S., Attaf, N. 2013. "Influence of Sn Content on Properties of $\mathrm{ZnO}: \mathrm{SnO} 2$ Thin Films Deposited by Ultrasonic Spray Pyrolysis", Materials Science in Semiconductor Processing, Volume 16, Issue 6, Pages 2021-2027.

Zhou, Q., Ji, Z., Hu, B., Chen, C., Zhao, L., Wang, C. 2007. "Low resistivity transparent conducting $\mathrm{CdO}$ thin films deposited by $\mathrm{DC}$ reactive magnetron sputtering at room temperature", Mater. Lett., 61, (2), 531. 